\title{
PERAN BK DALAM IDENTIFIKASI KEBUTUHAN DAN MASALAH SISWA (IKMS) UNTUK MENINGKATKAN HASIL BELAJAR
}

\author{
Wachid Hadicahyono \\ SMAN 1 Pagaden \\ Jl. Cipunagara No 32, Desa Sukamulya, Kecamatan Pagaden, Kabupaten Subang \\ wachid_satu@yahoo.com
}

\begin{abstract}
Abstrak---Identification of student needs and problems is one of the instruments used in this study. The aims and objectives of this study were a response to the decline in student motivation at SMAN 1 Pagaden. The author as a counseling teacher collaborates with the homeroom teacher and subject teacher to find a formulation that can increase student motivation again. Furthermore, this study is an effort to improve student learning outcomes in Class X IPS 2 which is based on statistics among other class X IPS, on average, students experience difficulties in learning. This can be seen from the achievement of scores where many students get scores below the KKM (Minimum Completeness criteria). Based on the results of the analysis of the identification of student needs and problems (IKMS), it was found that the lack of student motivation in Class X IPS 2 was caused by experiencing saturation with the monotonous teaching style of the teacher. These findings become recommendations to class XIPS 2 class teachers and subject teachers to change teaching styles. Different situations in the learning process actually provide a very significant increase in learning outcomes from around 57\% to $84 \%$. This research is expected to become a model of cooperation between subject teachers in order to produce integrated learning.
\end{abstract}

Key words : IKMS, the role of BK,learning,Motivation

Abstrak---Identifikasi kebutuhan dan masalah siswa merupakan salah satu instrumen yang digunakan dalam penelitian ini. Maksud dan tujuan dilakukan penelitian ini merupakan respon dari menurunnya motivasi belajar siswa di SMAN 1 Pagaden. Penulis sebagai guru BK berkolaborasi dengan wali kelas dan guru mata pelajaran untuk menemukan sebuah formulasi 
yang dapat meningkatkan kembali motivasi belajar siswa. Lebih lanjut penelitian ini, sebagai upaya meningkatkan hasil belajar siswa di Kelas X IPS 2 yang berdasarkan statistik diantara kelas X IPS yang lainnya rata-rata dalam pelajaran siswanya mengalami kesulitan dalam belajar. Hal ini dapat dilihat dari capaian nilai siswa yang banyak mendapatkan nilai di bawah KKM (Kriteri Ketuntasan Minimum). Berdasarkan hasil analisa dari identifikasi kebutuhan dan masalah siswa (IKMS) didapati bahwa kurangnya motivasi belajar siswa di Kelas X IPS 2 yang disebabkan mengalami kejenuhan dengan gaya mengajar guru yang monoton. Temuan ini menjadi rekomendasi kepada walikelas Kelas X IPS 2 dan guru mata pelajaran untuk mengubah gaya mengajar. Situasi yang berbeda pada proses pembelajaran ternyata memberikan hasil belajar yang sangat sigifikan dari angka sekitar 57\% naik menjadi 84\%. Penelitan ini diharapkan menjadi sebuah model kerja sama antar guru mata pelajaran agar menghasilkan pembelajaran yang terpadu.

Kata Kunci : IKMS, Peran BK, motivasi belajar

\section{PENDAHULUAN}

Motivasi menjadi faktor utama dalam membangun semangat belajar peserta didik. Namun, pada kenyataannya motivasi belajar peserta didik sangat tergantung pada kondisi psikologi yang mempengaruhinya pada saat itu sehingga terkadang diperlukan bimbingan untuk kembali menemukan semangat untuk belajar. Pada penelitian ini akan dibuat sebuah instrumen untuk mengidentifikasi kebutuhan serta masalah siswa oleh guru Bimbingan dan Konseling di SMAN 1 Pagaden untuk meningkatkan kembali motivasi belajar peserta didik yang diharapkan akan berpengaruh terhadap prestasi belajar peserta didik. Motivasi dapat dibedakan menjadi motivasi intrisik dan motivasi ekstrisik. Dorongan yang muncul pada dirinya sendiri disebut dengan motivasi intrisik sedangkan dorongan yang tumbuh sebagai akibat dari pengaruh luar disebut dengan motivasi ekstrisik. Dalam hal ini peran dari guru BK adalah dalam upaya membangun motivasi ekstrinsik dengan memberikan solusi yang konstruktif.

SMAN 1 Pagaden memiliki karakter peserta didik yang dibangun oleh sosial budaya wilayah pertanian yang kurang memandang penting masalah pendidikan sehingga peserta didik memiliki kecenderungan mengikuti pola masyarakat yang sudah terbentuk. Membangun karakter yang sudah tertanam tentu bukan perkara yang mudah. Oleh karena itu, dituntut semua pihak yang 
terkait dengan pendidikan berperan aktif dalam memberikan pandangan yang berbeda mengenai pendidikan terutama peran aktif dari Guru BK. Pendidikan disini harus dipandang sebagai suatu alternatif bagi masyarakat dalam merubah status sosial masyarakat, artinya pendidikan harus hadir sebagai salah satu yang dibutuhkan masyarakat dalam upaya mendapatkan masa depan yang lebih baik. Dalam pandangan belajar sosial, "manusia itu tidak oleh kekuatan-kekuatan dari dalam dan juga tidak "dipukul" oleh stimulus-stimulus lingkungan. Namun, fungsi psikologi diterangkan sebagai interaksi yang kontinyu dan timbal balik dari determinan pribadi dan determinan lingkungan”. Bandura (dalam Ratna Wilis, 2006).

Dari hasil pemetaan belajar peserta didik di SMAN 1 Pagaden rata-rata masih kurang memuaskan. Dari data tersebut kemudian diambil langkah inisaitif penulis selaku guru bimbingan dan konseling yang berkoordinasi dengan wali kelas dan guru yang lainnya untuk menyusun sebuah instrumen dalam mengidentifikasi kabutuhan dan masalah siswa untuk mendorong peserta didik untuk meningkatkan motivasi belajarnya. Hubungan belajar dan motivasi menurut (Eggen \& Kauchack, 2012), yaitu; "belajar dan motivasi adalah saling terkait di mana seseorang tidak dapat benar-benar memahami pelajaran tanpa mempertimbangkan motivasi”.

Berdasarkan UU RI No. 20 tahun 2003 pasal 1 ayat 6 menjelaskan bahwa guru BK adalah konselor, konselor adalah pendidik, karena itu konselor harus berkompetensi sebagai pendidik. Memang kehadiran guru BK sangat diperlukan sebagai professional yang bertugas memberikan pelayanan dan bimbingan. Sedangkan Winkel (2012:27) berpendapat bahwa peran guru BK, guru BK adalah:

"Guru bimbingan dan konseling/konselor sekolah adalah tenaga professional, yang mencurahkan seluruh waktunya pada pelayanan bimbingan (full-time guidance counselor)." Membantu siswa dalam proses pengambilan keputusan diri, memahami diri, menerima diri, mengarahkan diri, mengenal lingkungan dunia dan masa depannya, merealisasikan keputusannya secara bertanggung jawab serta membantu siswa mengambil keputusan arah studi lanjutan yang tepat dengannya dan mengembangkan potensi yang dimiliki juga merupakan pelayanan bimbingan konseling 
Oleh karena itu keberadaan Guru Bimbingan dan Konseling sangat penting dalam mendukung dan meningkatkan mutu pendidikan di sekolah. Guru BK menurut Achmad Juntika Nurihsan (2011:54) adalah guru yang memiliki kemampuan dan kualitas kepribadian yang baik, memiliki pengetahuan dan keahlian profesional tentang pelayanan bimbingan dan konseling, serta pendidikan psikologi yang sesuai dengan tugas dan profesinya."

Dengan memperhatikan penjelasan di atas, jelas bahwa Guru Bimbingan dan Konseling adalah pendidik yang merupakan bagian dari pendidikan yang memiliki kemampuan dan kualitas untuk membantu siswa memahami diri, menyesuaikan diri, memecahkan masalah, membuat pilihan dan merealisasikan dirinya dalam kehidupan nyata serta mengembangkan potensi yang dimilikinya untuk mencapai perkembangan optimal.

Dalam Upaya pelayanan prima, guru BK harus memahami dengan baik tugas dan fungsinya. Tugas dan fungsi guru BK menurut Fenti Hikmawati (2011:35), yaitu:

"Guru BK pendidikan adalah guru BK yang bertugas dan bertanggung jawab dalam memberikan layanan bimbingan dan konseling kepada peserta didik di satuan pendidikan." Guru BK haruslah melaksanakan layanan bimbingan dan konseling yaitu mendidik, membimbing, dan mengembangkan kemampuan peserta didik (siswa) dalam memecahkan permasalahan yang dialami dan segala potensi melalui layanan bimbingan dan konseling yang sesuai dengan peran dan tugas sebagai guru bimbmbingan dan konseling.

Adapun tugas dan beban Guru BK menurut Peraturan Pemerintah Republik Indonesia Nomor 74 Tahun 2008 tentang Guru Pasal 54 butir 6 disebutkan bahwa:"Beban kerja guru bimbingan dan konseling atau konselor yang memperoleh tunjangan profesi dan maslahat tambahan adalah mengampu paling sedikit 150 (seratus lima puluh) peserta didik per tahun pada satu atau lebih satuan pendidikan “. Dan dijelaskan kembali melaluiPeraturan Pemerintah Republik Indonesia Nomor 74 Tahun 2008 Tentang Guru Pasal 54 butir 6 bahwa: Yang dimaksud dengan "mengampu layanan bimbingan dan konseling" adalah pemberian perhatian, pengarahan, pengendalian, dan pengawasan kepada sekurang-kurangnya 150 (seratus lima puluh) peserta 
didik, yang dapat dilaksanakan dalam bentuk pelayanan tatap muka terjadwal di kelas dan layanan perseorangan atau kelompok bagi yang perlu dan yang memerlukan.

Oleh karena itu, Guru bimbingan dan konseling juga memiliki tugas untuk merancang program kegiatannya untuk secara aktif berpartisipasi dalam penumbuhan perilaku baik dan pengembangan diri siswa. Kegiatan tersebut dapat dilakukan secara mandiri yang terancang dalam program bimbingan dan konseling, dan juga bersama-sama dengan pendidik lain (guru bidang studi misalnya) yang terancang dalam program sekolah yang dilakukan secara sinergis dari beberapa pihak.

Menurut (Abu Bakar M. Luddin, 2010) menjelaskan mengenai tugas bimbingan konseling yang berhubungan dengan pengelolahan bimbingan konseling yaitu sebagai berikut:

"Tugas guru pembimbing/konselor adalah: memasyarakatkan kegiatan bimbingan dan konseling, merencanakan program bimbingan dan konseling, melaksanakan layanan bimbingan dan konseling terhadap sejumlah siswa yang menjadi tanggung jawabnya minimal sebanyak 150 siswa, melaksanakan kegiatan penunjang bimbingan dan konseling, menilai proses dan hasil kegiatan layanan bimbingan dan konseling, menganalisis hasil penilaian, melaksanakan tindak lanjut berdasarkan hasil analisis penilaian, mengadministrasikan kegiatan bimbingan dan konseling, mempertanggungjawabkan tugas dan kegiatan kepada koordinator guru pembimbing."

Penelitian yang dilakukan oleh (Sri Sugiarto, Riadi Suhendra, 2008) menekankan pentingnya siswa belajar sesuai dengan minat dan bakatnya serta pentingnya data mengenai cara belajar siswa yang bervariasi. Hal ini penting diketahui oleh guru BK agar tidak menerapkan pola yang sama terhadap selurus siswa disaat melakukan proses belajar mengajar.

Pada penelitian ini penulis selaku guru Bimbingan dan Konseling mengadakan duskusi dengan wali kelas dan beberapa guru mata pelajaran guna memantau grafik keberhasilan belajar peserta didik setelah diberikan motivasi yang berbasis Identifikasi Kebutuhan dan Masalah Siswa (IKMS) di SMAN 1 Pagaden. Penulis selaku guru BK memiliki catatan penting mengenai karakteristik peserta didik, kesulitan yang dihadapi peserta didik, serta pola belajar peserta didik. Berdasarkan catatan tersebut maka disusun sebuah skala prioritas untuk meningkatkan hasil 
belajar siswa dengan kembali memberikan motivasi sebelum kegiatan belajar mengajar berlangsung. Disamping itu, secara kolaboratif disampaikan kepada walikelas dan seluruh guru mata pelajaran di Kelas X IPS 2 untuk mengganti gaya mengajar agar memberikan suasana yang tidak monoton.

Hal senada diungkapkan oleh (Heri Nurdin,Chandra Ertikan, 2015) meningkatkan minat belajar siswa dapat dilakukan dengan cara memperbaiki proses belajar yang monoton. Kegiatan belajar mengajar yang didominasi oleh guru saat ini harus sudah perlahan diganti dengan pola belajar yang menekankan siswa aktif belajar. Melibatkan siswa dalam proses belajar mengajar ternyata lebih efektif dibandingkan siswa hanya menjadi pendengar.

\section{METODE}

\section{Partisipan}

Rangkaian penelitian ini diawali dengan membuat sampel pada populasi siswa di SMAN 1 Pagaden. Mengingat jumlah populasi siswa di SMAN 1 Pagaden yang berjumlah 1.380 siswa dari jenjang kelas X sampai kelas XII. Sehingga mengambil sampel penelitian di kelas X IPS 2 yang secara statistik, dalam hasil belajar masih kurang memuaskan bila dibandingkan dengan perolahan hasil belajar di kelas X IPS lainya.

\section{Desain}

Secara metodologi penelitian ini bersifat kualitatif dengan menjabarkan data hasil penelitian secara deskriptif.

\section{Prosedur}

Dalam penelitian ini akan melibatkan guru yang mengajar di Kelas X IPS 2 serta wali kelas guna melihat grafik perkembangan belajar peserta didik sebagai indikator keberhasilan penlitian. Penelitian tindakan kelas ini akan dibuat dengan skema dua siklus, pada pertemuan pertama guru BK akan memberikan motivasi sebelum kegiatan belajar berlangsung. Pada siklus kedua Guru 
BK akan berkoordinasi dengan guru mata pelajaran mengenai kondisi peserta didik serta hal apa yang perlu diperbaiki pada siklus kedua. Kemudian data dari kedua siklus akan dikomprasikan untuk melihat efektifitas mengenai peran Guru BK dalam identifikasi kebutuhan dan masalah siswa di SMAN 1 Pagaden.

Tujuan dari penelitian ini adalah menyusun sebuah instrumen yang dapat mengidentifikasi kebutuhan dan masalah siswa sehingga dari data instrumen tersebut akan menjadi rekomendasi bagi wali kelas dan guru mata pelajaran. Rangkaian penelitian ini diawali dengan membuat sampel pada populasi siswa di SMAN 1 Pagaden. Mengingat jumlah populasi siswa di SMAN 1 Pagaden yang berjumlah 1.380 siswa dari jenjang kelas X sampai kelas XII. Pengembangan penelitian ini kemudian akan dikoordinasikan dengan wali kelas dan guru mata pelajaran. Dari hasil diskusi dengan wali kelas dan guru mata pelajaran maka diambil sampel di kelas X IPS 2 dengan pertimbangan nilai yang rata-rata kurang memuaskan bila dibandingkan dengan kelas $\mathrm{X}$ IPS yang lainnya..

\section{Tahapan Penelitian Kelas}

Gambar 1. Siklus Penelitian Tindakan Kelas

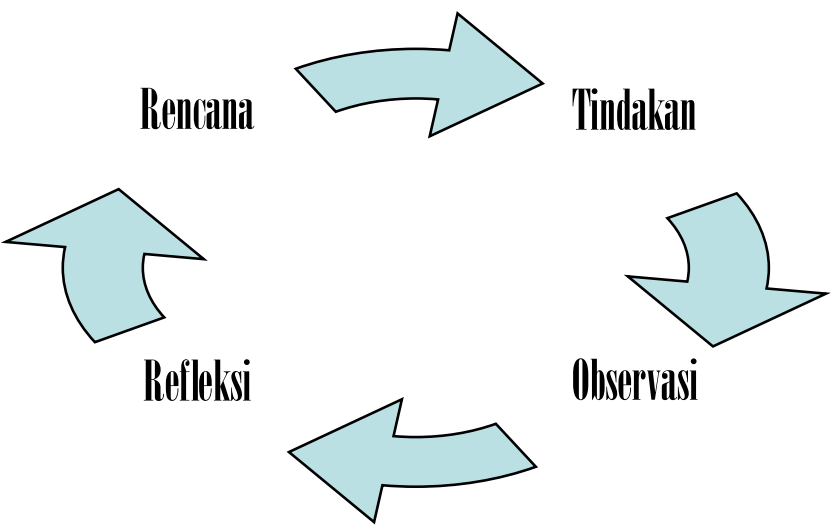

Untuk mendapatkan data pada penelitian ini menggunakan teknik obsevasi dan angket. Teknik observasi dengan melakukan pengamatan langsung mengenai hasil belajar siswa, seperti yang dijabarkan pada tabel berikut. 
Tabel 1 Hasil Belajar Siswa Siklus Pertama

\begin{tabular}{lcc}
\hline $\begin{array}{c}\text { Pencapaian Belajar } \\
\text { Siswa }\end{array}$ & Jumlah Responden & Persentase \\
\hline Mencapai KKM & 15 & $43 \%$ \\
\hline Tidak Mencapai KKM & 21 & $57 \%$ \\
\hline Sumber Data: Hasil Pengamatan Lapangan &
\end{tabular}

Selanjutnya data diperoleh dengan cara menyebarkan angket. Angket adalah satu teknik pengumpulan data yang berbentuk kumpulan pernyataan. Hal ini dimaksudkan untuk mengetahui sejauh mana respon atas peran guru BK dalam Identifikasi Masalah dan Kebutuhan Siswa dalam meningkatkan hasil belajar siswa. Penelitian ini menguji sampel sebanyak 36 siswa Kelas X IPS 2 yang terdiri atas, siswa perempuan yang berjumlah 23 orang dan siswa laki-laki yang berjumlah 13 orang.

\section{ANALISIS DAN HASIL}

\section{Siklus Pertama}

Pada siklus pertama akan diperoleh banyak data dan gambaran mengenai kondisi siswa di Kelas X IPS 2. Data ini sangat penting diketahui untuk menentukan langkah strategis yang akan dilakukan pada siklus kedua. Hal pertama yang dilakukan pada siklus pertama adalah menyusun sebuah perencanaan untuk melaksanakan kegiatan belajar mengajar dengan menyusun Rencana Pelaksanaan Pembelajaraan (RPP). Tahapan ini mencakup, penyusunan tujuan pembelajaran, indikator, metode pembelajaran dan evaluasi. Selanjutnya, dalam pelaksanaan tindakan adalah dengan memberikan motivasi oleh guru BK 15 menit sebelum kegiatan belajar mengajar berlangsung. Ini merupakan bentuk Identifikasi Masalah dan Kebutuhan Siswa, setelah memberikan motivasi maka guru BK mengelompokan siswa sesuai dengan pola belajarnya. Hal tersebut bertujuan agar guru yang mengajar di Kelas X IPS 2 dapat mengetahui pola belajar siswanya sehingga akan memberikan pendekatan yang tidak sama terhadap siswa. Selama kegiatan belajar mengajar berlangsung, guru BK melakukan pemantauan. Dengan melakukan pemantauan langsung terhadap kegiatan belajar mengajar maka dapat diamati kekurangan serta 
kelebihan selama proses belajar mengajar di siklus pertama. Dari hasil pemantauan ini kemudian dijadikan rujukan dalam tahap refleksi, tahapana ini akan membahas mengenai hasil selama kegiatan penelitian yang akan dijadikan rujukan perbaikan pada siklus kedua.

\section{Siklus Kedua}

Dasar yang digunakan untuk melaksanakan siklus kedua adalah hasil refleksi dari siklus pertama. Catatan yang diperoleh pada siklus pertama akan diperbaiki dan disempurnakan pada siklus kedua. Maka dari itu sebelum melakukan pengamatan di siklus kedua harus dibuat sebuah perencaan yang baik, karena pelaksanaan tanpa perencanaan yang baik tidak akan menghasilkan hasil yang baik. Tahap perencaan ini meliputi; penyusunan tujuan pembelajaran, indikator, metode pembelajaran dan evaluasi. Pelaksanaan tindakan Pelaksanaan siklus kedua, seperti pada siklus pertama. Guru BK meminta waktu kepada guru mata pelajaran sebelum kegiatan belajar mengajar dimulai untuk memberikan motivasi dan mengelompokan siswa. Pada prinsipnya pemantauan dilakukan selama proses penelitian berlangsung dengan sasaran utama adalah untuk melihat bagaimanakah proses pembelajaran berlangsung dengan pengelompokan siswa sesuai dengan cara belajarnya. Hal terakhir yang harus dilakukan pada siklus kedua adalah melakukan refleksi. Dari rekfleksi pada siklus kedua akan diketahui sejauh mana efektifitas dari peran guru BK dalam meningkatkan motivasi dan hasil belajar siswa.

Untuk melengkapi hasil penelitian maka disusun sebuah instrumen yang akan menghasilkan data mengenai identifikasi dan masalah siswa yang akan digunakan sebagai sebuah formulasi untuk meningkatkan motivasi belajar siswa. Instrumen ini digunakan sebagai panduan dalam melakukan angket dan wawancara kepada siswa dan membuat tabulasi persentase mengenai masalah-masalah yang sering kali dihadapi oleh peserta didik. Dari temuan hasil penelitian ini kemudian akan menjadi salah satu rekomendasi untuk disampaikan kepada pihak sekolah.

Dengan menggunakan angket di atas diperoleh data mengenai kesulitan-kesulitan siswa dalam belajar sehingga diperlukan adanya langkah konstruktif yang dilakukan agar dapat memberikan motivasi belajar sehingga akan berdampak pada hasil belajar. 


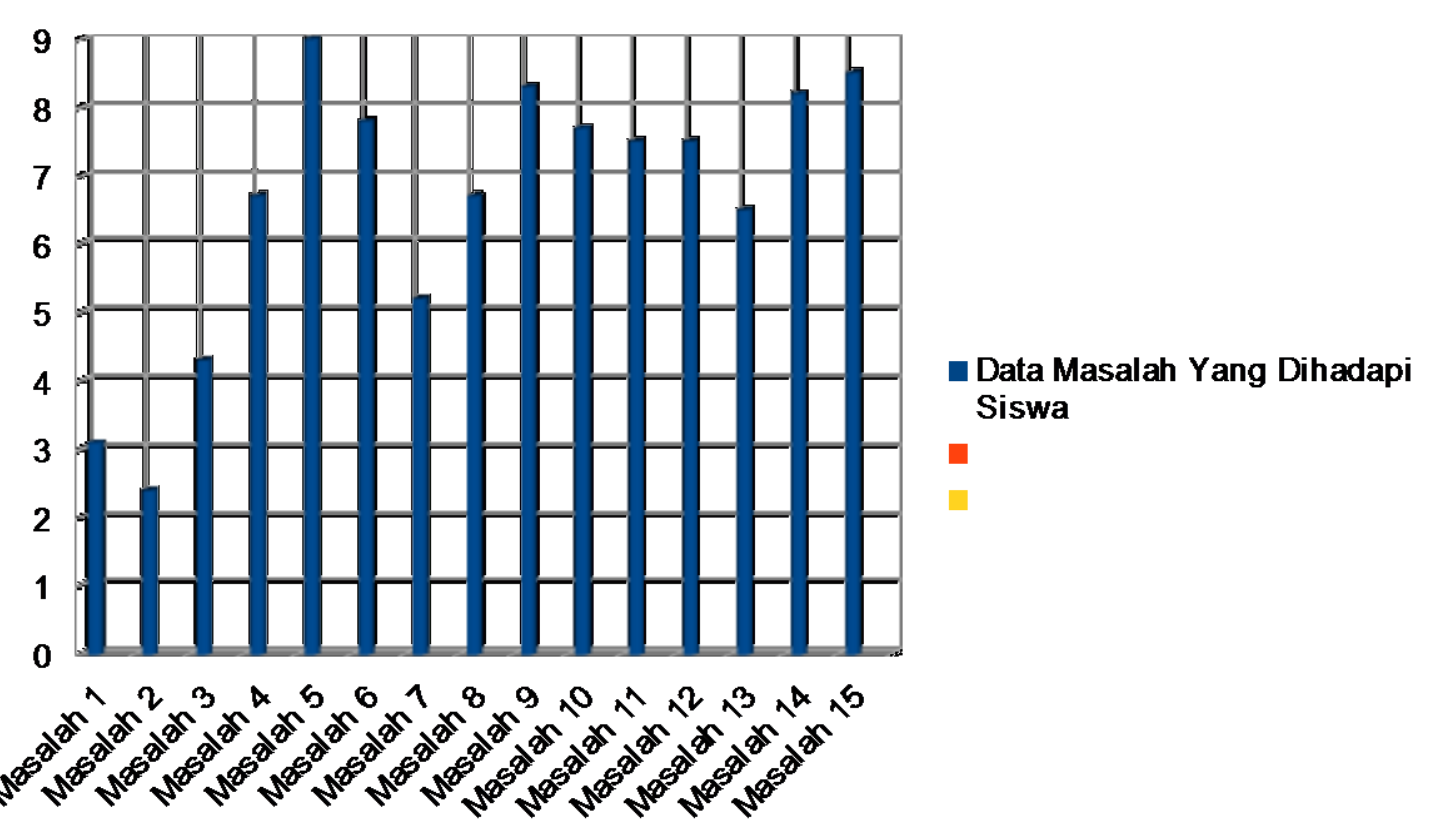

Berdasarkan data di atas dapat diuraikan masalah yang sering kali dihadapi oleh siswa ternyata siswa hampir 90\% sangat kesulitan dalam hal informasi menumbuhkan semangat belajar yang menurun. Dari data wawancara yang diperoleh, siswa sangat kesulitan menumbuhkan semangat dalam belajar terutama disaat siswa mengalami masalah yang dihadapi oleh sebagain besar oleh remaja yaitu masalah yang berkaiatan dengan kesukaan terhadap lawan jenis. Sebagai salah satu solusi dari masalah tersebut maka guru BK akan memberikan gambaran mengenai orang-orang berhasil mengatasi masalah percintaan, salah satunya tokoh yang sangat dikenal oleh mayoritas pelajar yaitu Mark Zuckerberg sebagai penemu facebook. Dalam kisah ini menceritakan bagaimana awal mula ditemukannya facebook karena masalah cinta yang dihadapi oleh Mark Zuckerberg, beliau merubah tantangan menjadi motivasi untuk menemukan sesuatu yang lebih bermanfaat.

Masalah lain yang berkaiatan dengan motivasi belajar siswa yaitu hampir sekitar $87 \%$ siswa tidak mengetahui bagaimana cara melakukan belajar yang efektif dan efisien. Hal ini sangat dipahami karena pada siswa kelas X mereka masih dalam upaya beradaptasi terhadap pola belajar sewaktu di SMP dan SMA yang jauh berbeda. Ada beberapa mata pelajaran yang baru dijumpai 
seperti geografi, ekonomi, sosiologi, sejarah di jurusan IPS sedangkan di IPA mereka menjumpai pelajaran seperti Fisika, Kimia, Biologi yang biasa terintegrasi dalam IPS terpadu dan IPA terpadu, namum di tingkat sekolah menengah mata pelajaran tersebut menjadi mata pelajaran yang mandiri. Hal ini akan menjadi catatan bagi guru mata pelajaran di kelas X untuk mengajarkan terlebih dahulu mengenai hakikat setiap ilmu pengetahuan agar siswa memahainya secara perlahan-lahan tidak langsung kepada subtansi atau isi dari setiap mata pelajaran.

Seperti pada remaja umumnya, hampir kebanyakan siswa SMAN 1 Pagaden mengalami kondisi Kurang mampu dalam mengatasi pengendalian diri, berpikir secara positif, dan kurang percaya diri. Hampir 92\% respon menyatakan kondisi tersebut dikeranakan kondisi sosial budaya di lingkungan rumahnya yang mayoritas pekerjaan orang tua sebagai buruh tani yang kurang mementingkan pendidikan. sikap skeptis terhadap pendidikan ditunjukan dengan rata-rata penduduk di sekitar SMAN 1 Pagaden paling tinggi hanya sampai sekolah tingkat menengah. Sehingga dibutuhkan peran yang proaktif dari guru BK dengan menyuguhkan pandangan yang berbeda tentang pendidikan, berkaitan dengan ini pendidikan dapat dijadikan investasi bagi masa depan.

Catatan penting lainnya adalah berkaiatan dengan jadwal, antara kegiatan di sekolah dengan aktivitas di luar sekolah. Sekitar $88 \%$ respon menyatakan bahwa jadwal sekolah yang padat membuat para siswa sulit untuk melakukan kegiatan di luar sekola seperti nongkrong dengan teman sebaya. Hal ini menyebabkan para siswa banyak yang beralasan untuk pulang malam karena aktivitas mereka di sekolah sampai sore hari. Aktivitas seperti ini akan mempengaruhi konsentrasi belajar karena kurang istirahat akibat nongrong sampai malam hari.

Data-data hasil temuan kemudian akan disampaikan secara terperinci kepada wali kelas dan guru mata pelajaran yang akan berkolaborasi dalam penelitian ini. Dari hasil penelitian, ada beberapa hal yang perlu diperhatikan, antara lain; (1) guru harus peka terhadap kondisi belajar siswa yang sedang beradaptasi dari pola belajar di SMP ke pola belajar siswa SMA, (2) guru mata pelajaran harus menyampaikan terlebih dahulu mengenai hakikat ilmu pengetahuan sebelum kepada hal yang subtansi, (3) guru mata pelajaran harus menggunakan metode belajar 
yang berbeda sehingga suasana kelas lebih menyenangkan, (4) guru mata pelajaran harus cermat dalam merotasi posisi duduk siswa, (5) guru mata pelajaran harus memberikan pandangan bahwa investasi yang sesungguhnya adalah pendidikan, dan (6) guru mata pelajaran harus mampu membaca bakat siswa sehingga dapat membuat pola kelompok yang tidak homogen.

\section{DISKUSI}

\section{Hasil Belajar Siswa Pada Siklus Pertama}

Berangkat dari permasalahan mengenai motivasi belajar yang sangat mempengaruhi prestasi belajar siswa, maka atas inisaitif dari penulis yang bekerja sama dengan berbagai unsur pendidikan di SMAN 1 Pagaden untuk segera menemukan sebuah formulasi yang dapat dengan segera meningkatkan motivasi belajar siswa. Dari inisaitif ini ditemukan banyak permasalah yang dihadapi oleh siswa untuk meningkatkan motivasi belajar salah satunya adalah berkaitan dengan metode mengajar dari guru yang cenderung kaku sehingga menyebabkan suasana menjadi membosankan.

Penulis memberikan rekomendasi kepada walikelas dan guru mata pelajaran yang kemudian direspon positif oleh guru mata pelajaran dengan menyusun suatu rancangan pembelajaran yang berbeda dengan situasi sebelumnya. Setelah berdiskusi maka walikelas dan guru yang mengajar di Kelas X IPS 2 mengambil suatu rancangan pembelajaran yang berbasis proyek untuk meningkatkan keaktifan siswa dalam belajar sehingga diharapkan dapat menimbulkan motivasi belajar dengan baik.

\section{Refleksi Siklus Pertama}

Dari hasil pengamatan pada siklus pertama ditemukan beberapa catatan penting, antara lain; 1) adanya perubahan sikap siswa terhadap materi setalah diberi motivasi oleh guru BK, 2) guru lebih mudah menyampaikan materi dengen pendekatan sesuai dengan karakteristik belajar siswa, 
3) siswa lebih mudah berdiskusi karena dikelompokan dengan siswa yang memiliki tipe belajar yang sama.

Proses pembelajaran akan lebih efektif jika akar permasalahan yang menjadi hambatan siswa dalam belajar dapat diketahui sumbernya agar pendekatan dalam proses belajar mengajar lebih tepat sassaran. Seperti dalam penelitian (Aswita Dian, 2015) bahwa proses belajar mengajar akan lebih baik jika melibatkan langsung siswa dalam proses belajar mengajar.

Hal ini senada dengan apa yang dikemukakan oleh Amstrong (Alamsyah Said \& Andi Budimanjaya, 2015: 32);

"strategi pembelajaran multiple intelligence adalah suatu cara mengakses informasi melalui delapan jalur kecerdasan yang ada pada masing-masing siswa, namun untuk mengeluarkannya kembali seluruh kecerdasan bersinergi dalam satu kesatuan yang unik sesuai dengan kebutuhan. Sehingga siswa mampu memecahkan masalah-masalah pembelajaran dengan cara yang menakjubkan".

Pembelajaran yang efektif adalah pembelajaran yang dapat melibatkan langsung peran serta peserta didik dalam kegiatan belajar mengajar (student centre). Pengalaman belajar peserta didik akan direduksi menjadi sebuah pengetahuan, peran guru tidak lagi dominan dalam kegiatan belajar mengajar

\section{Hasil Belajar Pada Siklus Kedua}

Dalam Siklus ini tentu saja akan mengalami perubahan bila dibandingkan pada pertemuan sebelumnya. Hal ini dimaklumi karena pada siklus kedua ini dilakukan upaya yang maksimal dari semua pihak terutama dari guru yang mengajar di Kelas X IPS 2 dengan menyusun suatu desain pembelajaran yang tidak seperti biasanya mengajar. Pada siklus kedua guru mata pelajaran berinisiatif untuk menerapkan pembelajaran berbasis proyek yang secara motorik maupun kognitif peserta didik lebih dominan dibanding guru. Artinya, guru pada siklus kedua ini hanya berperan sebagai fasilitator untuk memandu jalan diskusi antar siswa. 
Dibandingkan pada siklus pertama, hasil post tes pada siklus kedua menunjukan angka yang sangat signifikan dalam menunjukan grafik yang positif. Sehingga kegiatan ini harus terus mendapatkan apresiasi dari semua guru mata dan walikelas di SMAN 1 Pagaden.

\section{Refleksi Penelitian Pada Siklus Kedua}

Tentu saja keberhasilan ini merupakan kerja keras antara guru BP, walikelas, dan guru mata pelajaran. Penulis selaku guru BP terus berupaya mencari sebuah stimulus untuk membuat respon siswa menjadi lebih aktif dalam pembelajaran. Apa saja yang diberikan oleh guru dan yang diterima oleh siswa harus dapat diamati dan diukur untuk melihat perubahan yang terjadi dalam proses belajar mengajar (Irwan Novi, 2016).

Dari dua siklus yang telah dilakukan pada penelitian ini, maka diperoleh hasil akhir berupa grafik dari nilai siswa pada siklus pertama dan siklus kedua. Pada siklus pertama hasil belajar siswa menunjukan hasil sebesar 57\% siswa yang tuntas dalam pembelajaran. Angka tersebut memang masih kurang optimal sehingga upaya maksimal dilakukan pada siklus kedua. Dari hasil pengolahan data pada siklus kedua, hasil belajar menunjukan peningkatan hasil yang sangat sigifikan sekitar $84 \%$ siswa yang tuntas dalam pembelajaran.

Secara umum dapat dilihat bahwa pembelajaran dengan berbasis proyek pada mata pelajaran yang diterapkan di kelas X IPS 2 SMAN 1 Pagaden merubah suasana belajar mengajar menjadi lebih proaktif serta dapat meningkatkan hasil belajar siswa secara siginifikan. Pembelajaran kolaboratif antara guru BK, walikelas, dan guru mata pelajaran telah mendapatkan respon positif atau hasil yang memuaskan dalam meningkatkan motivasi belajar siswa sehingga berdampak pada hasil belajar.

Tabel 2 Hasil Belajar Siswa Siklus Kedua

\begin{tabular}{lcc}
\hline $\begin{array}{c}\text { Pencapaian Belajar } \\
\text { Siswa }\end{array}$ & Jumlah Responden & Persentase \\
\hline Mencapai KKM & 30 & $84 \%$ \\
\hline Tidak Mencapai KKM & 6 & $16 \%$ \\
\hline
\end{tabular}


Melihat grafik pada hasil penelitian menunjukan trend positif pada hasil belajar siswa. Hal terjedi karena rekomendasi dari peneliti selaku guru BK kepada wali kelas dan guru mata pelajaran dijalankan dengan baik. Instrumen Identifikasi Kebutuhan dan Masalah siswa dapat menjadi salah satu upaya dari guru BK dalam meningkatkan motivasi dan hasil belajar siswa di SMAN 1 Pagaden berhasil dengan baik.

\section{SIMPULAN DAN SARAN}

\section{Simpulan}

Berangkat dari masalah hasil belajar siswa di SMAN 1 Pagaden di Kelas X IPS 2. Guru mata pelajaran melakukan pembelajaran kolaboratif dengan guru BK guna mengetahui hambatanhambatan yang dialami oleh siswa dalam proses belajar mengajar, hambatan tersebut kemudian dianalisis dengan menggunakan Instrumen Kebutuhan dan Masalah Siswa sehingga dapat dikembangkan model pembelajaran yang tepat bagi siswa di Kelas X IPS 2 SMAN 1 Pagaden.

\section{Saran}

Penelitian yang berbasis Instrumen Kebutuhan dan Masalah Siswa bisa dijadikan rujukan dalam meningkatkan motivasi dan hasil belajar siswa. Sehingga perlu dilakukan diskusi dengan semua guru mata pelajaran agar siswa dapat belajar lebih baik lagi. Data primer mengenai keadaan siswa dapat menjadi salah satu rujukan penting bagi walikelas dan terutama bagi guru mata pelajaran agar dapat menciptakan suasana kelas yang tidak kaku dengan membuat suatu metode pembelajaran yang dapat meningkatkan motivasi belajar bagi siswa. Hal ini sangat penting karena berkaiatan dengan peningkatan mutu pembelajaran terutama di lingkungan SMAN 1 Pagaden. 


\section{REFERENSI}

Amstrong, Thomas. (2015). Sekolah Para Juara: Menerapkan Multiple Intelligences di Dunia Pendidikan. Jakarta: Gramedia Pustaka Utama.

Arikunto, Suharsimi. (2010). Prosedur Penelitian: Suatu Pendekatan Praktek. Jakarta: Rineka Cipta.

Aswita, Dian. (2015) Identifikasi Masalah Yang Dihadapi Guru Biologi Dalam Pelaksanaan Pembelajaran Pada Materi Ekosistem. Vol 3 No.1 halaman 63-68, 23/05/2015 tersedia di doi $\quad$ http://dx.doi.org/10.22373/biotik.v3i1.993

Budiningsih,Sri. (2012). Belajar dan Pembelajaran. Jakarta: PT. Rineka Cipta.

Dahar, Ratna Wilis. (1989). Teori-Teori Belajar. Jakarta: Penerbit Erlangga.

Departemen Pendidikan Nasional, (2005). Kamus Besar Bahasa Indonesia, Jakarta: Balai Pustaka.

Direktorat Jendral Peningkatan Mutu Pendidik Dan Tenaga Kependidikan Departeman Pendidikan Nasional. (2009). Pedoman Pelaksanaan Tugas Dan Pengawas, Jakarta: Departeman Pendidikan Nasional

Eggen,Paul dan Don Kauchak. (2012). Strategi dan Model Pembelajaran. Jakarta: Indeks.

Heri Nurdin, Chandra Ertikanto, (2015). Deskripsi Analisis Kebutuhan Pembelajaran Ilmu Pengetahuan Alam (IPA) Kelas VII Di Sekolah Menengah Pertama Negeri Gisting. Vol IV halaman $11-15, \quad 30 / 10 / 2015 \quad$ tersedia di http://journal.unj.ac.id/unj/index.php/prosidingsnf/article/view/5018

Hikmawati, Fenti. (2011). Bimbingan dan Konseling. Jakarta: PT. Raja Grafindo Persada

Irwan Novi. (2016). Penerapan Teori Belajar Behavioristik Dalam Proses Pembelajaran. Vol 1 halaman 64-74, 12/12/2016 tersedia di http://jurnal.umtapsel.ac.id/index.php/nusantara/article/ view/94/94

Luddin, Abu Bakar M., (2010). Dasar - Dasar Konseling, Bandung: Ciptapustaka Media Perintis. 
Nurihsan, Achmad Juntika. (2009). Bimbingan dan Konseling (Dalam Berbagai Latar

Kehidupan). Bandung: PT. Refika Aditama.

Peraturan Pemerintah Republik Indonesia Nomor. 74 Tahun 2008 tentang Tugas Guru BK/Konselor dan Pengawasan Bimbingan dan Konseling.

Ruhyat, (2018). Meningkatkan Hasil Belajar Melalui Pendekatan Interpersonal di SMPN 3 Pagaden. Vol 17, No.3 halaman 274-294, 3/10/2018 tersedia di DOI https://doi.org/10.17509/e.v17i3.14337.g9045

Sri Sugiarto, Riadi Suhendra, (2018). Pendampingan Terhadap Guru sekolah Menengah Pertama Mengidentifikasi Masalah Belajar Siswa Pada Mata Pelajaran Bahasa Indonesia. Vol 2, No.2 Halaman 12-18, 20/02/2018 tersedia di https://osf.io/84qb7/download

Subrata. (2019). Meningkatkan Hasil Belajar Siswa Melalui Pendekatan Visual-Spasial. Pedagogia, Vol 17, No 1 halaman 23-34, 25/4/2019 tersedia di DOI https://doi.org/10.17509/pdgia.v17i1.15783

Subadi, Tjibto. (2010). Lesson Study Berbasis PTK (Penelitian Tindakan Kelas) Suatu Model Pembinaan Menuju Guru Profesional. Surakarta: Badan Penerbit FKIP UMS.

Sugiyono. (2008). Memahami penelitian kualitatif. Bandung: Alfabeta.

Supriatna, Mamat. (2011). Bimbingan dan Konseling Berbasis Kompetensi (Orientasi Dasar Pengembangan Profesi Konselor). Jakarta: RajaGrafindo Persada

Winkel, W.S \& M.M Sri Hastuti. (2006). Bimbingan dan Konseling di Institusi Pendidikan. Yogyakarta: Media Abadi 